\title{
Embedded Instrumentation Based Soil pH Measurement System
}

\author{
B.SalehaBegum ${ }^{1}$, A.Suresh Kumar ${ }^{2}$ \\ 1. Research Scholar, Department of Instrumentation, S.V.University, Thirupathi, A.P, India. \\ 2. Department of USIC, S.V.University, Thirupati, A.P, India.
}

\begin{abstract}
Soil pH is a measure of hydronium ion (more commonly the H+) activity in the soil solution. Activity is similar to concentration in non-salt-affected soils. Soil pH influences many facets of crop production and soil chemistry, including availabilities of nutrients and toxic substances, activities and nature of microbial populations, and activities of certain pesticides. Soil pH is defined as the negative logarithm (base 10) of the H+ activity (moles per liter) in the soil solution. As the activity of $\mathrm{H}+$ in the soil solution increases, the soil $\mathrm{pH}$ value decreases. Soils with $\mathrm{pH}$ values below $\mathrm{pH} 7$ are referred to as "acid" and those with $\mathrm{pH}$ values above $\mathrm{pH}$ 7 as "alkaline"; soils at pH 7 are referred to as "neutral." Hence in present study an attempt is made to implement Embedded based Soil pH meter.
\end{abstract}

Keywords: Acidity, Agriculture, Alkalinity, Analyzer, Instrumentation, Salinity, Soil.

\section{Introduction}

$\mathrm{pH}$ is defined as the negative logarithm of the hydrogen ion concentration. This definition of $\mathrm{pH}$ was introduced by Danish chemist Soren Peder Lauritz Sorensen at the Carlsberg Laboratory in 1909. It is expressed mathematically as

$$
\text { pH }=-\log [\mathrm{H}+]
$$

where $[\mathrm{H}+]$ is hydrozen ion concentration in $\mathrm{mol} / \mathrm{L}$.

The $\mathrm{pH}$ value is an expression of the ratio of $[\mathrm{H}+]$ to $[\mathrm{OH}-]$. Therefore $[\mathrm{H}+]$ is greater than $[\mathrm{OH}-]$ the solution is called as acidic. Conversely if the $[\mathrm{OH}-]$ is greater than $[\mathrm{H}+]$ the solution will be basic. At $7 \mathrm{pH}$ the ration of $[\mathrm{H}+]$ to $[\mathrm{OH}-]$ is equal and therefore the solution is neutral. $\mathrm{pH}$ is a logarithmic function, a change of on $\mathrm{pH}$ unit represents a 10 -fold change in concentration ion.

In a neutral solution the $[\mathrm{H}+]=1 \times 10^{-7} \mathrm{~mol} / \mathrm{L}$

$$
\begin{array}{rlrl}
\text { i.e } \mathrm{pH} & = & & -\log \left(1 \times 10^{-7}\right) \\
& = & -\left(\log 1+\log 10^{-7}\right) \\
& = & -(0.0+(-7)) \\
& = & 7
\end{array}
$$

\section{It represents a $\mathrm{pH}$ of 7}

Measuring $\mathrm{pH}$ involves comparing the potential of solutions with unknown $[\mathrm{H}+]$ to a known reference potential. $\mathrm{pH}$ meters convert the voltage ratio between a reference half-cell and a sensing half-cell to $\mathrm{pH}$ values. In acidic or alkaline solutions, the voltage on the outer membrane surface changes proportionally to changes in $[\mathrm{H}+]$. The $\mathrm{pH}$ meter detects the change in potential and determines $[\mathrm{H+}]$ of the unknown by the Nernst equation:

$$
\mathrm{E}=\mathrm{Eo}+(2.3 \mathrm{RT}) / \mathrm{nF} \log \{\text { unknown }[\mathrm{H}+] / \text { internal }[\mathrm{H}+]\}
$$

Where: $\mathrm{E}=$ total potential difference $($ measured in $\mathrm{mV}$ ); Eo $=$ reference potential; $\mathrm{R}=$ gas constant; $\mathrm{T}=$ temperature in Kelvin; $\mathrm{n}=$ number of electrons; $\mathrm{F}=$ Faraday's constant; $[\mathrm{H}+]=$ hydrogen ion concentration.

\section{Theory}

The $\mathrm{pH}$ unit measures the degree of acidity of basicity of a solution. To be more exact $\mathrm{pH}$ is the measurement of the hydrogen ion concentration $[\mathrm{H}+]$. Every aqueous solution can be measured to determine its $\mathrm{pH}$ value. This value ranges from 0 to $14 \mathrm{pH}$. If the $\mathrm{pH}$ value of a solution is below $7 \mathrm{pH}$ then it has acidic properties. In the same way the $\mathrm{pH}$ of a solution is above $7 \mathrm{pH}$ then it will have basic (caustic/alkaline) properties. Since $7 \mathrm{pH}$ is the Centre of the measurement scale. It is neither acid nor basic. Therefore it is called as neutral. The $\mathrm{pH}$ scale is as follows. 


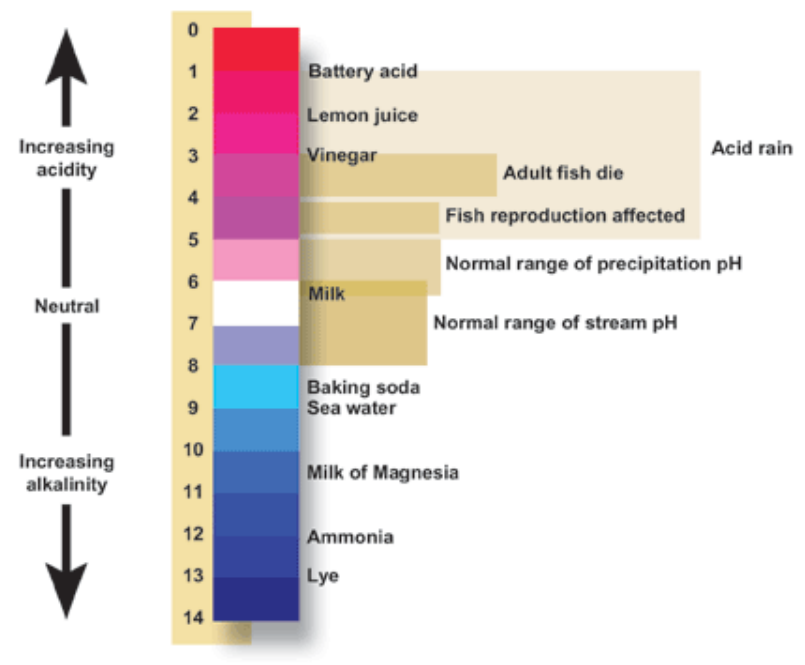

\section{Importance Of Ph Measurement}

Most of the living things depend up on a proper $\mathrm{pH}$ level to sustain life. All human beings and animals rely on internal mechanism to maintain the $\mathrm{pH}$ level of their blood. The blood flowing through veins must have a $\mathrm{pH}$ between 7.35 to 7.45 . Exceeding this range by as little as one tenth of a $\mathrm{pH}$ unit could prove fatal. Commodities such as wheat and corn not mention other plants and food products will grow best in soil of they are planted in is maintained at an optimal $\mathrm{pH}$. To attain high crop yields farmers must condition their fields to the correct $\mathrm{pH}$ value.

\section{PH CELL}

There are three types of electrodes used in the determination of $\mathrm{pH}$ :

(i) Reference Electrodes

(ii) $\mathrm{pH}$ Electrodes

(iii) Combination Electrodes ( $\mathrm{pH}$ and reference electrode in one sensor)

In the present study we are using the combination Electrode to measure the $\mathrm{pH}$ value of a solution

Combination $\mathrm{pH}$ Electrode as follows.

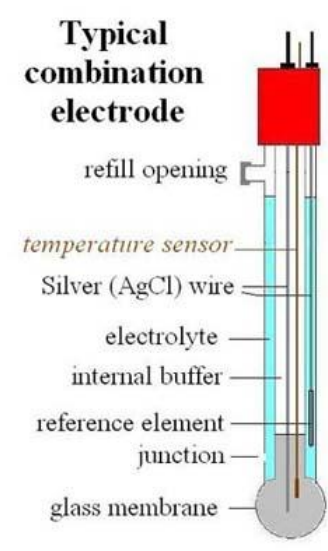

Figure 1: Combination Electrode

The combination $\mathrm{pH}$ electrode consists of a glass electrode concentrically surrounded by the reference electrode, see the figure1. The shaft can be made of glass or plastic. The $\mathrm{pH}$ sensitive part of the electrode is the glass tip or the so-called glass membrane, at the bottom end of the electrode.

\section{Ph Measurement System}

The block diagram of the $\mathrm{pH}$ measurement system is shown in Figure 2. The $\mathrm{pH}$ electrode gives $\mathrm{DC}$ voltage corresponds to $\mathrm{pH}$ of the solutions under study. The slope of a glass $\mathrm{pH}$ electrode will be in the range of $50 \mathrm{mV}$ to $100 \mathrm{mV}$. This voltage is amplified by a DC amplifier and is digitized by an Analog to Digital converter. The digital signals are transferred to PC/Laptop using a 
Microcontroller. A program written in Computer display the corresponding $\mathrm{pH}$ values. Computerizations of measurements have lot of advantages. These measurements can be used to control process parameters in production of chemicals, fertilizers and food production.

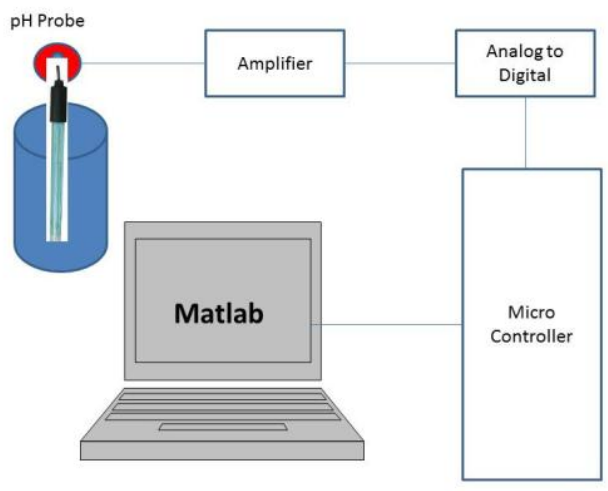

Figure 2: pH Measurement Block Diagram

A simple circuit diagram is shown in Figure 3. The glass $\mathrm{pH}$ electrode offers very high impedance. An amplifier is designed using an operational amplifier CA3140. The op-amp is configured in non-inverting mod, which offers very high input impedance. The output of the amplifier is connected to microcontroller PIC18F4550. This microcontroller have built analog to digital converter. A program written in $\mathrm{C}$ language, which is running in microcontroller digitize the analog voltage. This data is transferred to PC using a serial or USB interface.

In the present study a low cost controller kit is used, called Pinguino Kit. Details of the board and programming procedures can be found at www.pinguino.cc.

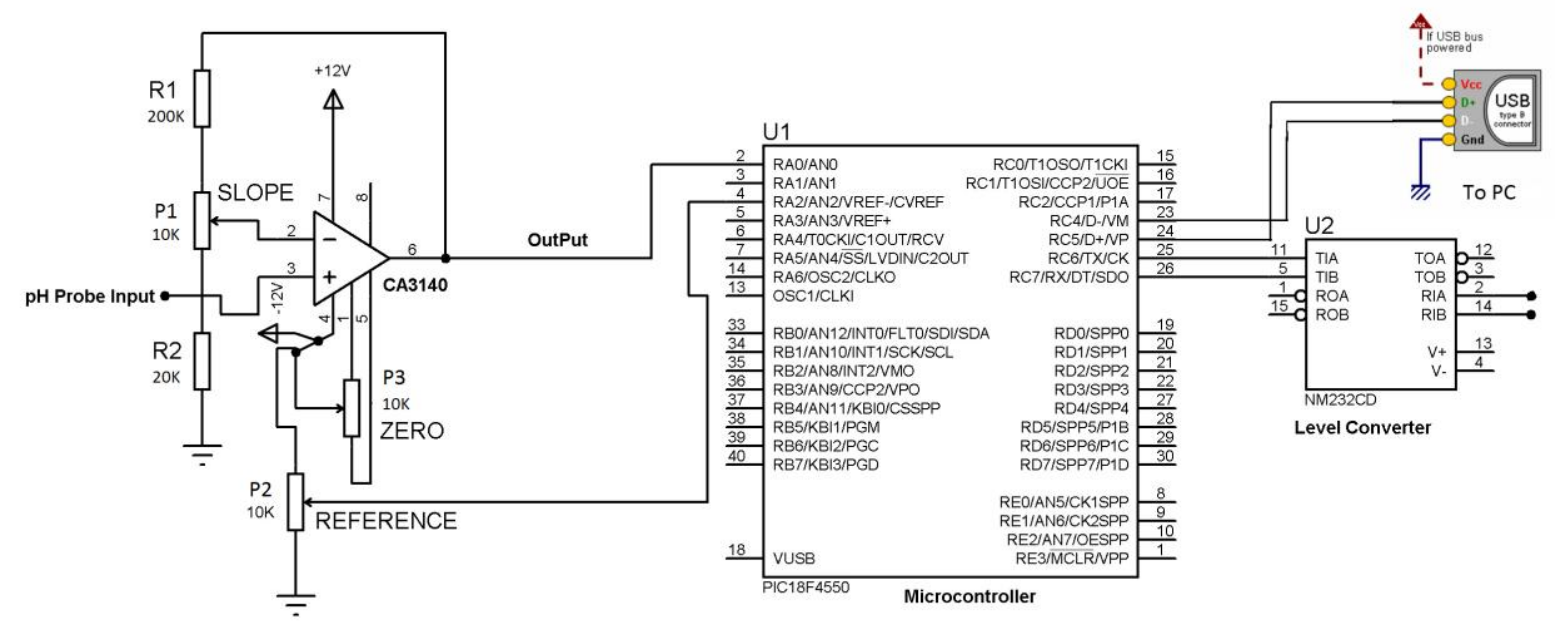

Figure 3: Circuit diagram of pH measurement

A host program running in the computer displays the $\mathrm{pH}$ values on the screen of computer. A typical screen shot of the measurement system is shown in Figure 4. A program written in MATLAB is used to measure the pH in real time. The data can be stored and further processed for other applications. 


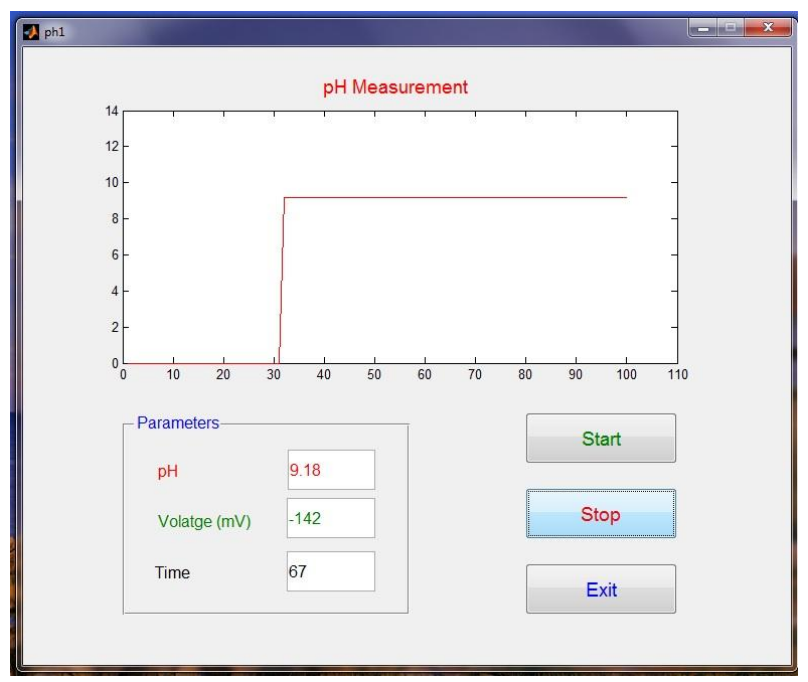

Figure 4 : Screen shot of the pH measurement system

\section{Calibration Procedure}

1. Adjust the potentiometer $\mathrm{P} 2$ by measuring the voltage at pin 4 of microcontroller to $-5 \mathrm{~V}$. This makes the range of Analog to digital converter $+5 \mathrm{~V}$ to $-5 \mathrm{~V}$.

2. Null the amplifier by shorting the $\mathrm{pH}$ probe input to ground. Measure the voltage between output + and ground. Adjust the potentiometer P3 until the voltage show zero volt (or close to zero) at the output of Amplifier.

3. Apply a known voltage of $400 \mathrm{mV}$ at the input, then measure the + output and ground using the digital voltmeter and adjust P1 to read 4.00 volt. This makes the amplifier to a gain of 10 .

4. Now connect the $\mathrm{pH}$ glass electrode to the amplifier and immerse the electrode in distilled water. The voltage reading on the screen is offset of the probe.

5. Immerse the $\mathrm{pH}$ electrode in standard solution of $\mathrm{pH} 4$ or 9.2. Note down the voltage. Form these values compute the slope of the electrode. These values are inserted in to formula, which is written in MATLAB program running in computer. Now the system is calibrated.

6. Now the $\mathrm{pH}$ meter is ready to use. The GUI displays $\mathrm{pH}$ and voltage on the screen. A plot updates real time measurement of $\mathrm{pH}$ readings.

\section{Known solution pH}

\section{Results}

\begin{tabular}{|c|c|c|}
\hline $\begin{array}{c}\text { Standard Buffer } \\
\text { Solutions }\end{array}$ & $\begin{array}{c}\text { Measured Values With Existing } \\
\text { Meter }\end{array}$ & Measured Values in Present Study \\
\hline 4 & 4.01 & 4.02 \\
\hline 7 & 7.04 & 7.05 \\
\hline 9.2 & 9.19 & 9.18 \\
\hline
\end{tabular}

\section{Unknown Solution pH}

\begin{tabular}{|c|c|c|}
\hline Village of the soil sample & $\begin{array}{c}\mathrm{pH} \text { Measured At Soil Testing } \\
\text { Office }\end{array}$ & $\mathrm{pH}$ Measured In Present Study \\
\hline Y.Kottapalli & 6.65 & 6.66 \\
\hline Garudapuram & 7.36 & 7.37 \\
\hline Mallapuram & 6.17 & 6.16 \\
\hline
\end{tabular}

\section{Conclusion}

By using "Instrumentation based soil $\mathrm{pH}$ analyzer", we can measure $\mathrm{pH}$ values using a glass electrode together with a low cost embedded system. By connecting the system to the PC measurement can be done and plotted real time.

This device is more economical, reliable, and portable. Using this instrument, farmers can measure $\mathrm{pH}$ manually or in real time with regular intervals. Real time monitoring is important, where the electrode is fitted in the drip irrigation system, where we can monitor the $\mathrm{pH}$ of the fluids pumped in the drip irrigation channels. Using this system farmer can evaluate the soil nutrients present in the soil and lack of percentage of nutrients to be added for a specific crop by using predefined data provided. A farmer can have the suggestions from soil analysts or agricultural scientists through Internet, so that he can improve the crop yields in an efficient manner. 


\section{References}

[1]. Galster, H. pH Measurement; VCH: Weinheim, Germany, 1991.

[2]. Skoog, D. A.; West, D. M.; Holler, F. J. Fundamentals of Analytical Chemistry,6th ed.; Saunders: Philadelphia, PA. 1992.

[3]. Harris, D. C. Quantitative Chemical Analysis, 4th ed.; Freeman: NY, 1998.

[4]. Handbook of Electronic Technology 3rd. ed.; Orion Research: Cambridge, U.K., 1982.

[5]. Practice and Theory of $\mathrm{pH}$ Measurement; Ingold: Urdorf, Switzerland, 1989.

[6]. Temsamani, K. L.; Cheng, K. L. Sensors and Actuators B 2001, 76, 551-555

[7]. Milazzo, G.; Sagloo, C. Tables of Standard Electrode Potentials; Wiley: New York, 1978.

[8]. Bates, R. Determination of $\mathrm{pH}$, 2nd ed.: Wiley: New York, 1974.

[9]. Bockris, J. O’M.; Reddy, A.K.N. Modern Electrochemistry; Plenum: New York, 1970; p. 18,

[10]. Wu, Y. C.; Koch, W. F.; Marinenko, G. J. Res. NBC 1989, 395.

[11]. Adams, F. and C. E. Evans. 1962. A rapid method for measuring lime requirement of red-yellow podzolic soils. Soil Sci. Soc. Amer. Proc. 26:355-357.

[12]. Graham, E. R. 1959. An explanation of theory and methods of soil testing. Missouri Agric. Exp. Stn. Bull. 734.

\section{Books}

1. WHAT IS pH, AND HOW IS IT MEASURED?

A Technical Handbook for Industry

By Frederick J. Kohlmann (C) Hach

http://www.alliancets.com/site/files/408/29497/109873/159912/Guide_to_pH_Measurement.pdf

http://ebookbrowse.com/1-08-ss-ia-c-ee-nptel-pdf-d73174056

http://www.raihome.com

http://www.radiometer-analytical.com

www.hach.com/smartprobes

http://www.edn.com/design/test-and-measurement/4340776/Convert-your-DMM-to-a-pH-meter

Http://www.freecircuitdiagrams.com/

http://www.ehow.com/how_7778032_make-homemade-ph-meter.html

http://en.wikipedia.org/wiki/Nernst_equation

http://wiki.pinguino.cc/images/a/aa/PIC18F4550 diagram.png 